Check for updates

Cite this: RSC Adv., 2019, 9, 40024

Received 19th October 2019 Accepted 28th November 2019

DOI: 10.1039/c9ra08561k

rsc.li/rsc-advances

\title{
Effects of size on the photocatalytic properties of high-index faceted pseudocubic and rhombohedral $\alpha-\mathrm{Fe}_{2} \mathrm{O}_{3}$ nanocrystals $\uparrow$
}

\author{
Zhuan Wang, ${ }^{a}$ Wenyu Xie, ${ }^{\mathrm{b}}$ Bo Yang, ${ }^{\mathrm{a}}$ Li Song, ${ }^{\mathrm{a}}$ Xueying Zhao, ${ }^{\mathrm{a}}$ Aslam Khan, ${ }^{\mathrm{a}}$ Fan Yue, ${ }^{\mathrm{a}}$ \\ Xintai Su (iD ${ }^{\mathrm{c}}$ and Chao Yang (D) *a
}

\begin{abstract}
Size-controlled and high-index faceted $\alpha-\mathrm{Fe}_{2} \mathrm{O}_{3}$ nanocrystals with pseudocubic and rhombohedral morphologies were synthesized through the hydrothermal treatment of $\beta$ - $\mathrm{FeOOH}$ at different $\mathrm{pHs}$. The size effect on the photocatalytic oxygen evolution efficiency of high-index faceted $\alpha$ - $\mathrm{Fe}_{2} \mathrm{O}_{3}$ nanocrystals was investigated. Rhombohedral $\alpha-\mathrm{Fe}_{2} \mathrm{O}_{3}(\mathrm{pH}$ 6.0) exhibits an outstanding apparent quantum yield of $9.93 \%$ and an oxygen evolution efficiency of $20.3 \%$, which can be attributed to the optimal size and high-indexed $\{104\}$ planes. This work provides a new idea for the design of high activity water oxidation catalysts, through the size optimization of high-index faceted materials.
\end{abstract}

\section{Introduction}

Given the growing energy consumption and environmental pollution caused by fossil fuel combustion, one of the biggest challenges of this century is the search for clean and renewable energy sources. ${ }^{1}$ Currently, the direct conversion of solar energy into chemical energy by photocatalytic water splitting has aroused widespread interest. Nonetheless, in the water splitting context, the water oxidation reaction has to overcome higher energy barriers, and is thought to be the bottleneck of water splitting. ${ }^{2}$ Thus, much effort has been devoted to the design and construction of highly efficient water oxidation catalysts (WOCs). Although $\mathrm{IrO}_{2}$ and $\mathrm{RuO}_{2}$ are considered to be the most efficient catalysts for water oxidation, ${ }^{3,4}$ their extremely high cost makes researchers turn their research enthusiasm to cheap transition metal catalysts. A large number of transition metal compounds, including $\mathrm{Co},{ }^{5,6} \mathrm{Cu},{ }^{7} \mathrm{Mn},{ }^{8-10} \mathrm{~W},{ }^{11-13}$ and $\mathrm{Fe},{ }^{14-16}$ have been explored as WOCs. Among these compounds, ironbased WOCs have attracted much attention due to their low cost and low toxicity. ${ }^{17,18}$

$\alpha-\mathrm{Fe}_{2} \mathrm{O}_{3}$, because of its proper bandgap, has been extensively utilized as the photocatalyst or cocatalyst for oxygen evolution, ${ }^{19}$

${ }^{a}$ Ministry Key Laboratory of Oil and Gas Fine Chemicals, College of the Chemistry and Chemical Engineering, Xinjiang University, Urumqi 830046, China. E-mail: jerryyang1924@163.com

${ }^{b}$ Guangdong Provincial Key Laboratory of Petrochemcial Pollution Processes and Control, School of Environmental Science and Engineering, Guangdong University of Petrochemical Technology, Maoming, Guangdong 525000, China

'The Key Laboratory of Pollution Control and Ecosystem Restoration in Industry Clusters (Ministry of Education), School of Environment and Energy, South China University of Technology, Guangzhou 510006, China

† Electronic supplementary information (ESI) available. See DOI: 10.1039/c9ra08561k hydrogen evolution, ${ }^{20} \mathrm{CO}_{2}$ reduction, ${ }^{21}$ and pollutant degradation. ${ }^{22-24}$ Considerable effort has been devoted to improving the photocatalytic oxygen evolution of $\alpha-\mathrm{Fe}_{2} \mathrm{O}_{3}$ based on the heterojunction construction. ${ }^{25-30}$ The composite structure of $\alpha-\mathrm{Fe}_{2} \mathrm{O}_{3} /$ rGO significantly improves the charge carries separation of $\alpha$ $\mathrm{Fe}_{2} \mathrm{O}_{3}$ and enhances the photocatalytic water oxidation performance. ${ }^{28}$ The tight hetero-junction structure of $\alpha-\mathrm{Fe}_{2} \mathrm{O}_{3} / \mathrm{g}-\mathrm{C}_{3} \mathrm{~N}_{4}$ has been demonstrated as active sites for visible-light-driven oxygen generation. ${ }^{25}$ The optimized integration of cocatalyst $\mathrm{CoO}_{x}$ enables hexagonal $\alpha-\mathrm{Fe}_{2} \mathrm{O}_{3}$ nanoplates with dramatically enhanced $\mathrm{O}_{2}$ evolution rate. ${ }^{26}$ The Pt nanoparticles decorated $\alpha$ $\mathrm{Fe}_{2} \mathrm{O}_{3}$ nanoplates structure exhibit the enhanced photoactivity and photostability for water oxidation. ${ }^{27}$ Besides, the fabrication of $\alpha-\mathrm{Fe}_{2} \mathrm{O}_{3}$ nanocrystals with specific shapes and sizes is also conducive to enhance the photocatalytic oxygen evolution ability. Moreover, the shape effect is essentially due to the arrangement of atoms on different exposed crystal faces. Plenty of work has confirmed that the $\{012\}$ and $\{104\}$ planes of $\alpha$ $\mathrm{Fe}_{2} \mathrm{O}_{3}$ are high-index planes. ${ }^{31-34} \mathrm{Ma}$ et al. found that the exposed $\{104\}$ planes of $\alpha-\mathrm{Fe}_{2} \mathrm{O}_{3}$ exhibits excellent gas sensing properties. ${ }^{33}$ Zhao et al. investigated that $\alpha-\mathrm{Fe}_{2} \mathrm{O}_{3}$ nanocubes exposed $\{012\}$ active facets combination with graphene lead to boosted lithium storage capability. ${ }^{34}$ Recently, Xiang and coworkers reported that $\alpha-\mathrm{Fe}_{2} \mathrm{O}_{3}$ nanocubes with $\{012\}$ facets have much higher photocatalytic water oxidation activity than $\alpha-\mathrm{Fe}_{2} \mathrm{O}_{3}$ nanoflakes with $\{001\}$ facets. ${ }^{31}$ Wang et al. researched that $\alpha-\mathrm{Fe}_{2} \mathrm{O}_{3}$ enclosed by $\{012\}$ and $\{104\}$ facets can facilitate to increase the activity of photocatalytic oxygen evolution significantly. ${ }^{32}$ However, the size effect on the photocatalytic water oxidation performance of $\alpha-\mathrm{Fe}_{2} \mathrm{O}_{3}$ nanocrystals has been scarcely investigated. Moreover, the attempt to combine the size effect with the high-index facet to improve the photocatalytic activity of $\alpha-\mathrm{Fe}_{2} \mathrm{O}_{3}$ is significant. 
Here, we selectively synthesized pseudocubic and rhombohedral $\alpha-\mathrm{Fe}_{2} \mathrm{O}_{3}$ nanocrystals with varying sizes through the hydrothermal treatment of the $\beta$-FeOOH precursor at different $\mathrm{pH}$ values. By adjusting the $\mathrm{pH}$ value of the precursor, a morphology evolution of $\alpha-\mathrm{Fe}_{2} \mathrm{O}_{3}$ nanocrystals from $\{012\}$ pseudocubes to $\{104\}$ rhombohedrons was observed with the reduction in size. Through a comprehensive investigation of the factors affecting the oxygen production performance of the catalyst, we confirm the size-dependent photocatalytic water oxidation property of $\alpha-\mathrm{Fe}_{2} \mathrm{O}_{3}$. Moreover, we obtained $\{104\}$ planes faceted $\mathrm{Fe}_{2} \mathrm{O}_{3}$ (pH 6.0) possessing excellent photocatalytic oxygen evolution performance.

\section{Experimental}

\section{Materials}

Ferric chloride hexahydrate $\left(\mathrm{FeCl}_{3} \cdot 6 \mathrm{H}_{2} \mathrm{O}\right)$, sodium hydroxide $(\mathrm{NaOH})$ were purchased from Tianjin Zhiyuan Chemical Reagent Co., Ltd. All chemicals were of analytical grade and used directly without further purification.

\section{Fabrication of $\alpha-\mathrm{Fe}_{2} \mathrm{O}_{3}$ nanocrystals}

The synthesis route was carried out according to the literature with a slight modification. ${ }^{35}$ When synthesizing $\alpha-\mathrm{Fe}_{2} \mathrm{O}_{3}$, $0.024 \mathrm{~mol} \mathrm{FeCl}_{3} \cdot 6 \mathrm{H}_{2} \mathrm{O}$ was dissolved in $600 \mathrm{~mL}$ deionized water, refluxed and stirred at $78^{\circ} \mathrm{C}$ for $12 \mathrm{~h}$ to obtain a brown $\beta$-FeOOH solution with an initial pH value of 1.2 (measured by a LICHEN $\mathrm{pH}$ meter). The solution was divided into four equal portions, and the $\mathrm{pH}$ value of each portion was tuned with $\mathrm{NaOH}$ $\left(1 \mathrm{~mol} \mathrm{~L}^{-1}\right)$ aqueous solution to 1.2, 2.0, 4.0, and 6.0, respectively. Subsequently, four $1 \mathrm{~L}$ Teflon autoclaves were used to encapsulate the $\beta$ - $\mathrm{FeOOH}$ solutions with different $\mathrm{pHs}$, which were then heated to $150{ }^{\circ} \mathrm{C}$ for $10 \mathrm{~h}$. After natural cooling to room temperature, it was washed with ethanol and water several times and dried at $40{ }^{\circ} \mathrm{C}$. The final products were labeled as $\mathrm{Fe}_{2} \mathrm{O}_{3}-1.2, \mathrm{Fe}_{2} \mathrm{O}_{3}-2.0, \mathrm{Fe}_{2} \mathrm{O}_{3}-4.0$, and $\mathrm{Fe}_{2} \mathrm{O}_{3}-6.0$, respectively.

\section{Characterizations}

The crystalline phase of the as-synthesized products was identified by X-ray diffraction (XRD) (BRUKER D8 Advance) at a scanning rate of $5^{\circ} \mathrm{min}^{-1}$ in $2 \theta$ ranging from $10^{\circ}$ to $80^{\circ}$. A Hitachi S-4800 scanning electron microscope was used to obtain the scanning electron microscopy (SEM) images at $5 \mathrm{kV}$. The transmission electron microscopy (TEM) images were obtained on an FEI Tecnai G2 f20 s-twin with an accelerating voltage of $200 \mathrm{kV}$. The UV-vis absorption spectra of as-obtained catalysts were obtained by a Hitachi U-3010 spectrophotometer. The Brunauer-Emmett-Teller (BET) surface areas of the products were evaluated by $\mathrm{N}_{2}$ adsorption-desorption measurements at $77 \mathrm{~K}$ (liquid nitrogen) in an automated surface area and porosity analyzer (ASAP2020, Micromeritics, USA). Photoluminescence spectra (PL) of the catalysts were characterized with a fluorescence spectrophotometer (Hitachi-F-4500) with an exciting wavelength of $300 \mathrm{~nm}$. The particle size distribution was measured by Nanomeasure software.

\section{Photocatalytic oxygen evolution measurements}

Photocatalytic water oxidation tests were performed in a buffer solution with an argon atmosphere at room temperature. In this experiment, $5.0 \mathrm{mg}$ of $\alpha-\mathrm{Fe}_{2} \mathrm{O}_{3}$ was dispersed in a $10.0 \mathrm{~mL}$ $80.0 \mathrm{mM}$ sodium borate buffer solution containing $1.0 \mathrm{mM}$ $\left[\mathrm{Ru}(\mathrm{bpy})_{3}\right]\left(\mathrm{ClO}_{4}\right)_{2}$ and $20.0 \mathrm{mM} \mathrm{Na} \mathrm{Na}_{2} \mathrm{O}_{8}$, and sealed with a rubber gasket in a $20 \mathrm{~mL}$ round-bottom flask. The solution was to degas the air with argon and then irradiated it with visible light ( $300 \mathrm{~W}$ Xe lamp, $\lambda>420 \mathrm{~nm}$ ) at room temperature. Every two minutes, $\mathrm{O}_{2}$ in the top air was sampled with a $100 \mu \mathrm{L}$ syringe and analyzed by GC-TCD equipped with a $5 \AA$ molecular sieve column.

\section{Photoelectrochemical measurements}

The transient photocurrent response was performed on a Chi 660D electrochemical workstation using a standard threeelectrode system with $\mathrm{Ag} / \mathrm{AgCl}$ and $\mathrm{Pt}$ electrodes as the counter and reference electrodes, respectively. The working electrode was prepared as follows: $5.0 \mathrm{mg}$ of the as-synthesized sample was mixed with $1.0 \mathrm{~mL}$ of deionized water by ultrasonic treatment. Then, the mixture was coated on a $2.5 \mathrm{~cm} \times 1.5 \mathrm{~cm}$ F-doped $\mathrm{SnO}_{2}$-coated glass (FTO glass) electrode with approximately uniform thickness. Subsequently, the electrode was dried in vacuum at $110{ }^{\circ} \mathrm{C}$ for $10 \mathrm{~h}$, and $0.5 \mathrm{mM} \mathrm{Na} \mathrm{S}_{2} \mathrm{O}_{4}$ aqueous solution was used as the electrolyte.

\section{Results and discussion}

Fig. 1 exhibits the XRD patterns of the precursor and products. All products have obvious diffraction peaks at $2 \theta=24.26^{\circ}$, $33.22^{\circ}, 35.73^{\circ}, 40.95^{\circ}, 43.65^{\circ}, 49.54^{\circ}, 54.10^{\circ}, 57.61^{\circ}, 62.50^{\circ}$, and $64.07^{\circ}$ could be indexed to the (012), (104), (110), (113), (024), (116), (018), (214), and (300) crystal planes, corresponding to the hexagonal hematite (JCPDS no. 33-0664). This result indicates that precursor $\beta$-FeOOH (JCPDS no. 34-1266) was completely transformed into to $\alpha-\mathrm{Fe}_{2} \mathrm{O}_{3}$ through the hydrothermal treatment under different initial pHs. ${ }^{36}$ The average crystallite sizes of $\alpha-\mathrm{Fe}_{2} \mathrm{O}_{3}$ nanocrystals prepared at $\mathrm{pH}$ values of 1.2, 2.0, 4.0, and 6.0 were $50.61,42.92,39.99$, and $37.06 \mathrm{~nm}$, respectively, which were calculated by Scherrer formula. ${ }^{37}$ The result demonstrates the crystallite size of the sample decrease with the increasing of precursor $\mathrm{pH}$ value.

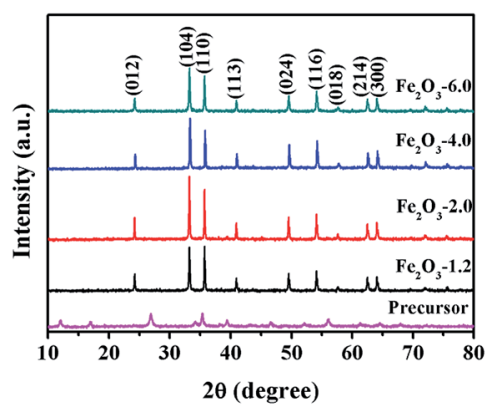

Fig. 1 XRD patterns of the precursor and samples $\mathrm{Fe}_{2} \mathrm{O}_{3}-x$ ( $x$ is 1.2, 2.0, 4.0, and 6.0). 

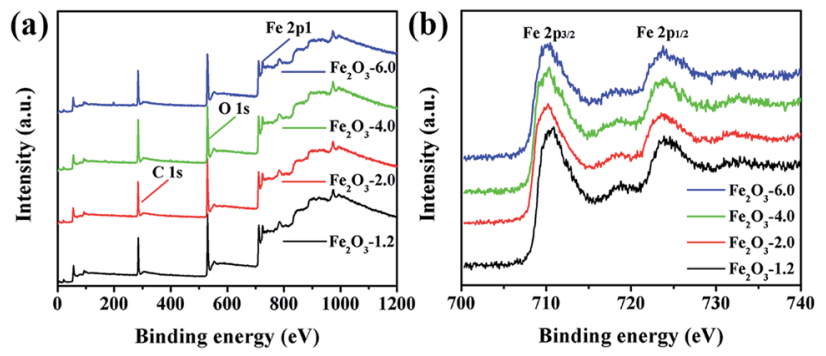

Fig. 2 XPS spectra of $\alpha-\mathrm{Fe}_{2} \mathrm{O}_{3}$ nanocrystals: (a) full survey spectrum of $\mathrm{Fe}_{2} \mathrm{O}_{3}-x$ ( $x$ is 1.2, 2.0, 4.0, and 6.0); (b) Fe 2p peaks of $\mathrm{Fe}_{2} \mathrm{O}_{3}-x$.

For further identifying the samples, the surface composition of the products was analyzed by XPS in Fig. 2. The XPS spectra of the samples display the same line shape, and the presence of $\mathrm{Fe}$, $\mathrm{O}$, and $\mathrm{C}$ elements in Fig. 2a demonstrates that the four substances have the same valence state of elements. The binding energy peaks at 710.3 and $723.8 \mathrm{eV}$ in the Fe 2p highresolution XPS spectrum (Fig. $2 b$ ) are attributed to $\mathrm{Fe} 2 \mathrm{p}_{3 / 2}$ and $\mathrm{Fe} 2 \mathrm{p}_{1 / 2}$, respectively, which strongly proves that Fe element in iron oxide exists in the form of the $\mathrm{Fe}^{3+}$. The lineshape and binding energies of Fe $2 \mathrm{p}$ agree well with those reported in the literature. ${ }^{38}$

The size and morphology of the $\alpha-\mathrm{Fe}_{2} \mathrm{O}_{3}$ nanocrystals were characterized by SEM in Fig. 3. The schematic illustration in Fig. 3a shows the morphology and size evolution of $\alpha-\mathrm{Fe}_{2} \mathrm{O}_{3}$ nanocrystals with varying $\mathrm{pH}$ values. Fig. $3 \mathrm{~b}$ and $\mathrm{c}$ exhibit the products of $\mathrm{Fe}_{2} \mathrm{O}_{3}-1.2$ and $\mathrm{Fe}_{2} \mathrm{O}_{3}-2.0$ have the same pseudocubic morphology and different mean lengths of $c a .603$ and $507 \mathrm{~nm}$,

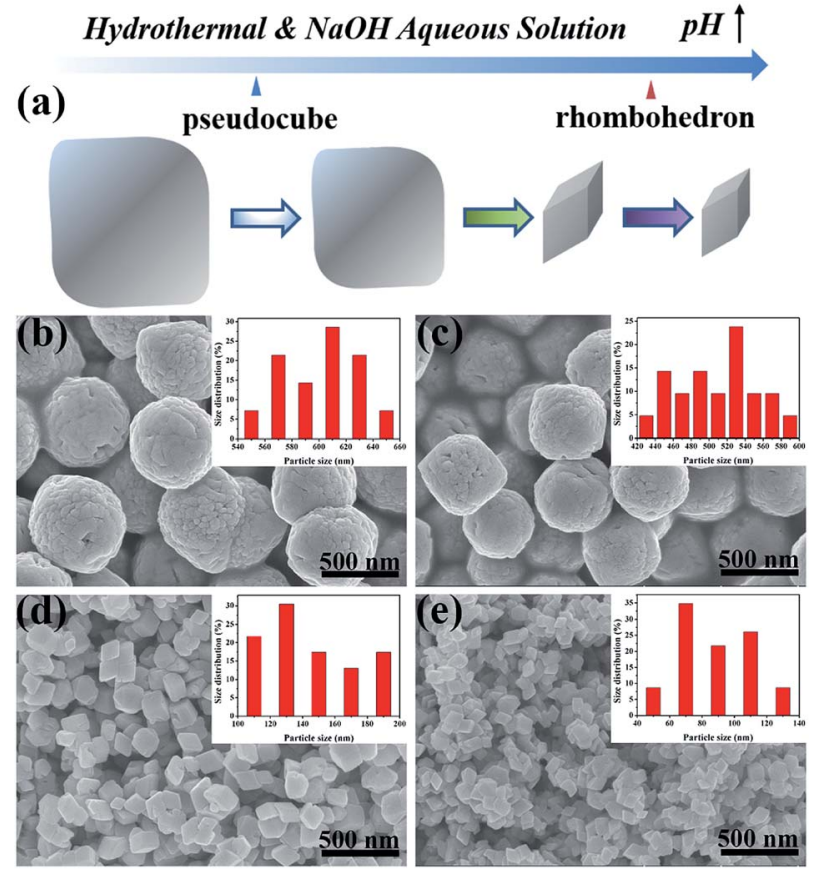

Fig. 3 (a) Schematic illustration of the growth of $\alpha-\mathrm{Fe}_{2} \mathrm{O}_{3}$ with $\mathrm{pH}$ change; (b-e) SEM images of the samples and inset of corresponding particle size distribution, (b) $\mathrm{Fe}_{2} \mathrm{O}_{3}-1.2$, (c) $\mathrm{Fe}_{2} \mathrm{O}_{3}-2$.0, (d) $\mathrm{Fe}_{2} \mathrm{O}_{3}-4.0$, and (e) $\mathrm{Fe}_{2} \mathrm{O}_{3}-6.0$. respectively. Moreover, rhombohedral $\alpha-\mathrm{Fe}_{2} \mathrm{O}_{3}$ with different average sizes of $c a .145$ and $88 \mathrm{~nm}$ were obtained at $\mathrm{pH} 4.0$ and 6.0, respectively (Fig. 3d and e). It is worth mentioning that the rough surface of pseudocubes mirrors the growth nature of the iron oxide, which is formed by the aggregation and fusion of plenty of small particles. The crystal growth behavior at the expense of small particles is consistent with the description of the Ostwald ripening mechanism. ${ }^{39}$ Hence, the Ostwald ripening mechanism could be used to explain $\alpha-\mathrm{Fe}_{2} \mathrm{O}_{3}$ growth behavior. Overall, the $\mathrm{pH}$ control process discloses that increasing the precursor $\mathrm{pH}$ not only contributes to the formation of smaller $\alpha$ $\mathrm{Fe}_{2} \mathrm{O}_{3}$ nanocrystals but also driving the shape transformation of $\alpha-\mathrm{Fe}_{2} \mathrm{O}_{3}$ from pseudocubic to rhombohedron.
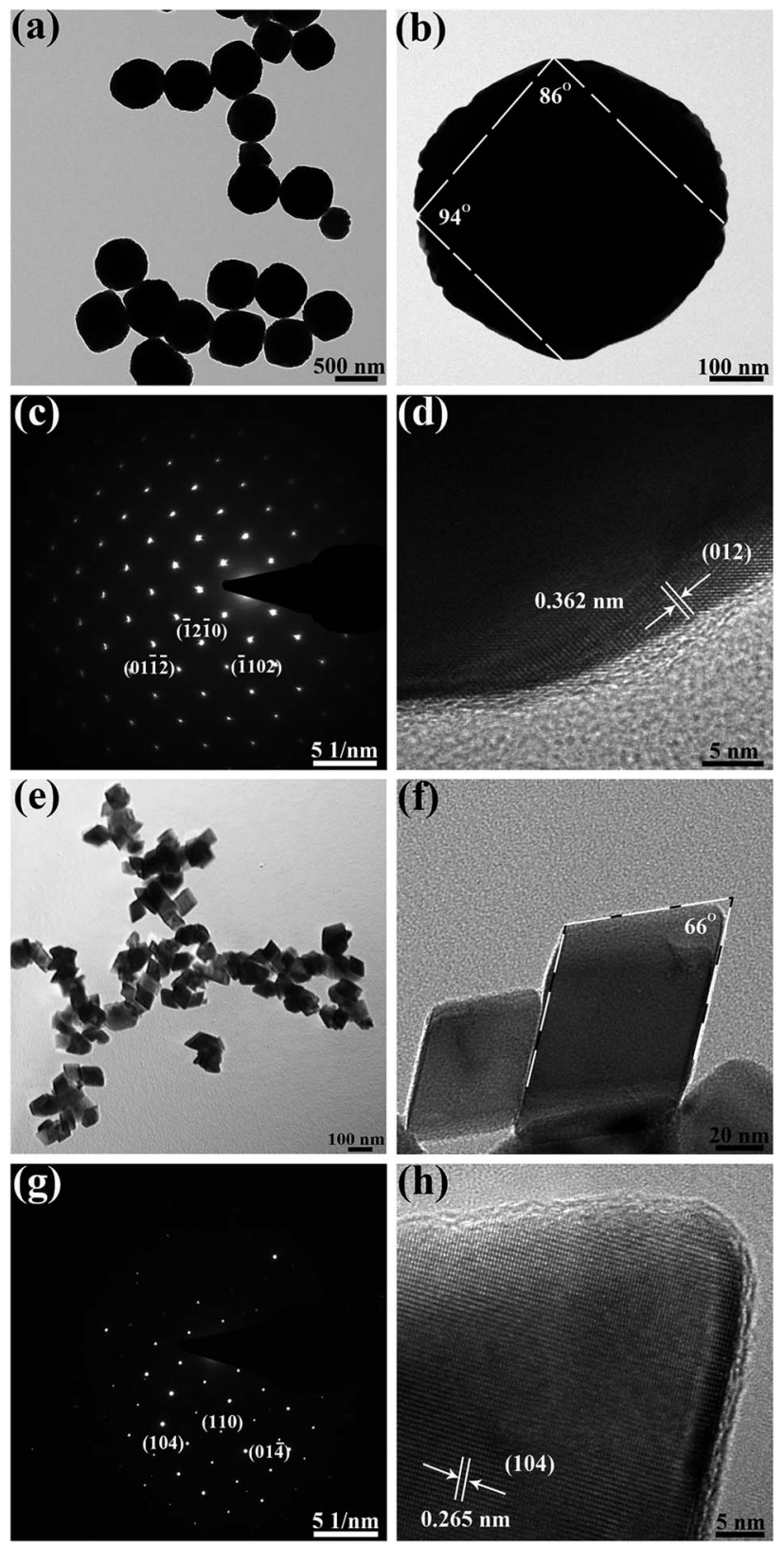

Fig. 4 (a, b) and (e, f) TEM, (c) and (g) SAED, (d) and (h) HRTEM images of pseudocubic $\alpha-\mathrm{Fe}_{2} \mathrm{O}_{3}\left(\mathrm{pH}\right.$ 1.2) and rhombohedral $\alpha-\mathrm{Fe}_{2} \mathrm{O}_{3}(\mathrm{pH} 6.0)$, respectively. 
(a)

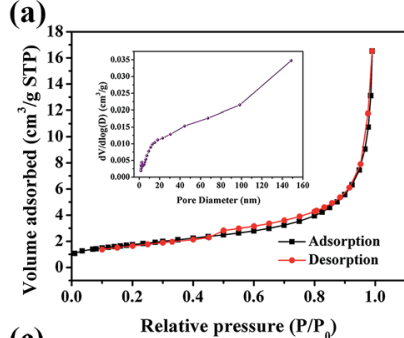

(c)

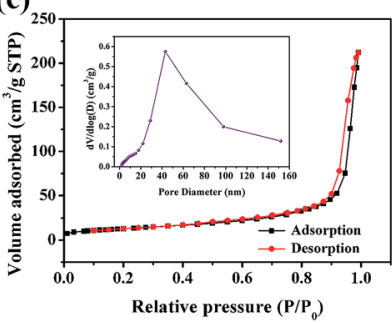

Fig. $5 \mathrm{~N}_{2}$ adsorption-desorption isotherm of sample (inset of Barrett-Joyner-Halenda pore size), (a) $\mathrm{Fe}_{2} \mathrm{O}_{3}-1.2$, (b) $\mathrm{Fe}_{2} \mathrm{O}_{3}-2.0$, (c) $\mathrm{Fe}_{2} \mathrm{O}_{3}-4.0$, and (d) $\mathrm{Fe}_{2} \mathrm{O}_{3}-6.0$.

High-resolution transmission electron microscopy (HRTEM) was employed to recognize the dominant active crystal planes of the two typical samples $\mathrm{Fe}_{2} \mathrm{O}_{3}-1.2$ and $\mathrm{Fe}_{2} \mathrm{O}_{3}$-6.0. TEM images and selected area electron diffraction (SAED) pattern of the pseudocubic $\alpha-\mathrm{Fe}_{2} \mathrm{O}_{3}$ (pH 1.2) are exhibited in Fig. 4a-d. Pseudocubic exhibits rhombus facets with dihedral angles between two adjacent facets are $86^{\circ}$ and $94^{\circ}$ (Fig. $4 \mathrm{~b}$ ). The ordered diffraction spots in the SEAD pattern (Fig. 4c) present the singlecrystalline structure of the pseudocubes. Further, the HRTEM shows the measured lattice spacing of the exposed facet is $0.362 \mathrm{~nm}$ (Fig. 4d), corresponding to the (012) facet of $\alpha-\mathrm{Fe}_{2} \mathrm{O}_{3}$. The above characteristics are consistent with the single-crystal $\alpha-\mathrm{Fe}_{2} \mathrm{O}_{3}$ pseudocubes enclosed by $\{012\}$ planes reported in the literature. ${ }^{40,41}$ Fig. $4 \mathrm{e}-\mathrm{g}$ exhibits the TEM images and SAED pattern of the rhombohedral $\alpha-\mathrm{Fe}_{2} \mathrm{O}_{3}$ (pH 6.0). TEM images in Fig. $4 \mathrm{e}$ and $\mathrm{g}$ reveal that the nanocrystals are $\alpha-\mathrm{Fe}_{2} \mathrm{O}_{3}$ rhombohedrons with a single-crystalline structure. The measured lattice fringe (Fig. $4 \mathrm{~h}$ ) is of $0.265 \mathrm{~nm}$, agree well with (104) plane of $\alpha-\mathrm{Fe}_{2} \mathrm{O}_{3}$. The dihedral angle measured in Fig. $4 \mathrm{f}$ is $66^{\circ}$, which can match with the theoretical value of $64.9^{\circ} .{ }^{42}$ These descriptions of $\alpha-\mathrm{Fe}_{2} \mathrm{O}_{3}$ (pH 6.0) are in agreement with the characteristics of rhombohedral iron oxide enclosed by $\{104\}$ planes. $^{43}$

Brunauer-Emmett-Teller (BET) adsorption/desorption isotherms and Barrett-Joyner-Halenda (BJH) pore size were used to characterize the surface properties of the catalysts

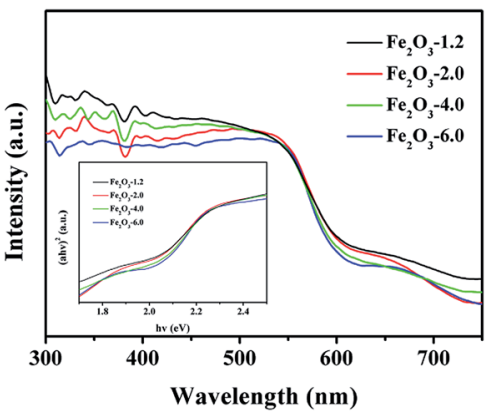

Fig. 6 UV-visible diffuse reflectance spectra of $\mathrm{Fe}_{2} \mathrm{O}_{3}-x$ (inset of Tauc plots).

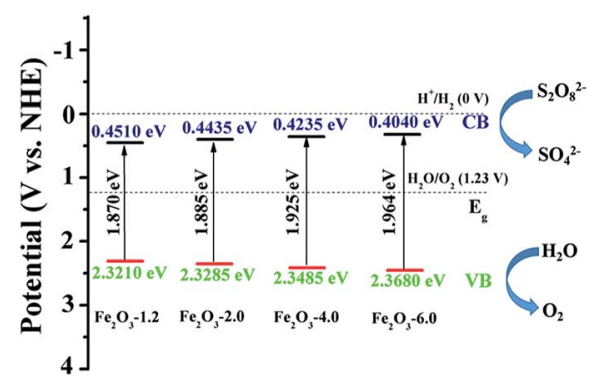

Fig. 7 Schematic drawing of redox potentials of $\mathrm{Fe}_{2} \mathrm{O}_{3}-X$.

(Fig. 5). Each isotherm corresponds to a type IV isotherm with a small hysteresis loop, indicating the presence of mesopores in the catalyst. The pore size distribution curves of four $\alpha-\mathrm{Fe}_{2} \mathrm{O}_{3}$ samples show that the pore size distribution ranges from 1.7 to $170 \mathrm{~nm}$, which confirms the existence of mesopores and macropores. The specific surface areas (Table 1) of catalysts calculated by the BET method are $6.29,8.93,47.03$, and $52.70 \mathrm{~m}^{2} \mathrm{~g}^{-1}$ corresponding to $\mathrm{Fe}_{2} \mathrm{O}_{3}-1.2, \mathrm{Fe}_{2} \mathrm{O}_{3}-2.0, \mathrm{Fe}_{2} \mathrm{O}_{3}-4.0$, and $\mathrm{Fe}_{2} \mathrm{O}_{3}-6.0$, respectively.

UV-vis diffuse reflectance spectra (Fig. 6) show that the absorption edges of all samples are longer than $600 \mathrm{~nm}$, which reflects the strong visible-light-harvesting ability of samples. Moreover, the absorption band edge of the product is blueshifted with an increase of the $\mathrm{pH}$ value, which could result from the quantum size effect. ${ }^{44}$ The bandgap of samples was determined from the Tauc plot (inset of Fig. 6), claiming the indirect bandgap of samples is $1.870,1.885,1.925$, and $1.964 \mathrm{eV}$, respectively. Combined with Mulliken electronegativity theory $\left(E_{\mathrm{CB}}=X-E_{\mathrm{C}}-1 / 2 E_{\mathrm{g}}, E_{\mathrm{VB}}=E_{\mathrm{CB}}+E_{\mathrm{g}}\right.$, where $X$ is absolute electronegativity, $E_{\mathrm{C}}$ is the energy of free electrons, $E_{\mathrm{VB}}$ is the

Table 1 Physicochemical properties and oxygen evolution activities of $\alpha-\mathrm{Fe}_{2} \mathrm{O}_{3}$ samples

\begin{tabular}{lllrl}
\hline Catalysts & Morphology & Dominant facets & Specific surface area $\left(\mathrm{m}^{2} \mathrm{~g}^{-1}\right)$ & $\mathrm{O}_{2}$ evolution $(\mu \mathrm{mol})$ \\
\hline $\mathrm{Fe}_{2} \mathrm{O}_{3}-1.2$ & Pseudocubic & $\{012\}$ & 6.29 & 2.71 \\
$\mathrm{Fe}_{2} \mathrm{O}_{3}-2.0$ & Pseudocubic & - & 8.93 & 3.28 \\
$\mathrm{Fe}_{2} \mathrm{O}_{3}-4.0$ & Rhombohedron & - & 47.03 & 16.28 \\
$\mathrm{Fe}_{2} \mathrm{O}_{3}-6.0$ & Rhombohedron & $\{104\}$ & 52.70 & 20.32
\end{tabular}




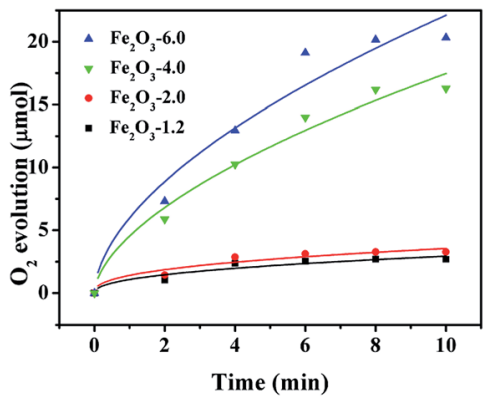

Fig. 8 Plots of oxygen evolution vs. time for visible-light-driven water oxidation by $\alpha-\mathrm{Fe}_{2} \mathrm{O}_{3}$ nanocrystals. Condition: $5.0 \mathrm{mg}$ catalyst, $\mathrm{Xe}$ lamp, $300 \mathrm{~W}, \lambda>420 \mathrm{~nm}, 100 \mathrm{~mW} \mathrm{~cm}{ }^{-2}, 10 \mathrm{~min}$ lumination, $1.0 \mathrm{mM}$ $\left[\mathrm{Ru}(\mathrm{bpy})_{3}\right]\left(\mathrm{ClO}_{4}\right)_{2}, 20.0 \mathrm{mM} \mathrm{Na} \mathrm{S}_{2} \mathrm{O}_{8}, 80.0 \mathrm{mM}$ sodium borate buffer (initial $\mathrm{pH}$ 9.0).

potential of the conduction band, and $E_{\mathrm{VB}}$ is the potential of the valence band), ${ }^{45}$ the $E_{\mathrm{VB}}$ and $E_{\mathrm{CB}}$ of the four samples are determined. As seen in Fig. 7, the valence bands of the semiconductors are greater than $1.23 \mathrm{~V}$, which meets the requirement of oxygen evolution kinetics. Moreover, the valence band becomes more positive with the increase of $\mathrm{pH}$ value, implying the enhance of water oxidation ability.

The curves in Fig. 8 display the amount of oxygen evolution of the four $\alpha-\mathrm{Fe}_{2} \mathrm{O}_{3}$ samples follows the order of $\mathrm{Fe}_{2} \mathrm{O}_{3}-6.0>$ $\mathrm{Fe}_{2} \mathrm{O}_{3}-4.0>\mathrm{Fe}_{2} \mathrm{O}_{3}-2.0>\mathrm{Fe}_{2} \mathrm{O}_{3}$-1.2. In particular, $\mathrm{Fe}_{2} \mathrm{O}_{3}-6.0$ possesses the maximum oxygen evolution of $20.32 \mu \mathrm{mol}$, almost 7.5 times that of $\mathrm{Fe}_{2} \mathrm{O}_{3}-1.2(2.71 \mu \mathrm{mol})$. In order to comprehensively analyze the influence of size and crystal surface factors on the oxygen production performance of the catalysts, we calculated the specific activity of the four samples. It can be seen intuitively that the specific activity of the four samples has not much difference (Fig. 9), especially the difference between $\mathrm{Fe}_{2} \mathrm{O}_{3}-6.0$ and $\mathrm{Fe}_{2} \mathrm{O}_{3}-1.2$ can almost be seen as a deviation. This result reflects size effect is the primary factor, which determines the oxygen evolution efficiency of $\{104\}$ planes faceted $\mathrm{Fe}_{2} \mathrm{O}_{3}-6.0$ superior to that of other catalysts. Moreover, compared with other iron-based catalysts (Table 2), $\mathrm{Fe}_{2} \mathrm{O}_{3}-6.0$ has an outstanding apparent quantum yield of $9.93 \%$ and an oxygen evolution efficiency of $20.3 \%$, which could be ascribed to the optimal size and high-activity planes. After five times of oxygen evolution performance test (Fig. 10), the oxygen evolution did

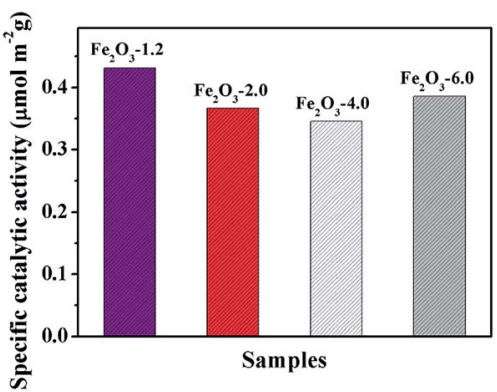

Fig. 9 Specific catalytic activities (the amount of $\mathrm{O}_{2}$ per unit surface area) of $\alpha-\mathrm{Fe}_{2} \mathrm{O}_{3}$ samples.
Table 2 Comparison of catalytic performance of different catalysts

\begin{tabular}{lcll}
\hline Catalysts & $\mathrm{O}_{2}(\mu \mathrm{mol})$ & $\mathrm{O}_{2}$ yield $^{a}(\%)$ & Reference \\
\hline $\mathrm{Fe}_{2} \mathrm{C}$ & 10.32 & 20.64 & 49 \\
$\mathrm{Fe}_{2} \mathrm{O}_{3}$ & 2.83 & 17.7 & 31 \\
$\mathrm{Fe}_{2} \mathrm{O}_{3}-6.0$ & 20.32 & 20.32 & This work \\
$\mathrm{Fe}_{2} \mathrm{O}_{3}-4.0$ & 16.28 & 16.28 & This work \\
$\mathrm{Fe}_{2} \mathrm{O}_{3}-2.0$ & 3.28 & 3.28 & This work \\
$\mathrm{Fe}_{2} \mathrm{O}_{3}-1.2$ & 2.71 & 2.71 & This work \\
$\mathrm{FeOOH}$ & 7.91 & 3.955 & 50 \\
$\mathrm{NiFe}_{2} \mathrm{O}_{4}$ & 3.7 & 7.40 & 51
\end{tabular}

${ }^{a}$ Yield is defined as twice the number of moles of $\mathrm{O}_{2}$ per mole of $\mathrm{Na}_{2} \mathrm{~S}_{2} \mathrm{O}_{8}$.

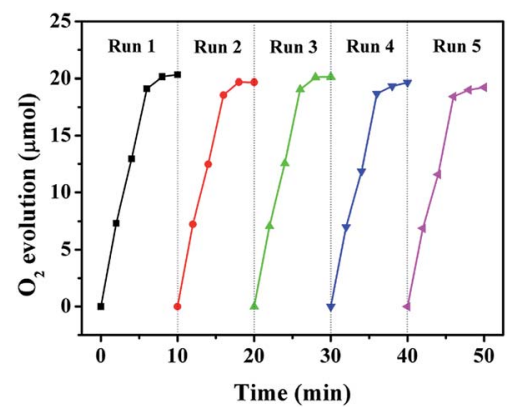

Fig. 10 Photostability study of $\mathrm{Fe}_{2} \mathrm{O}_{3}-6.0$ in the water oxidation reaction. Condition: $5.0 \mathrm{mg}$ catalyst, Xe lamp, $300 \mathrm{~W}, \lambda>420 \mathrm{~nm}, 100$ $\mathrm{mW} \mathrm{cm}{ }^{-2}, 1.0 \mathrm{mM}\left[\mathrm{Ru}(\mathrm{bpy})_{3}\right]\left(\mathrm{ClO}_{4}\right)_{2}, 20.0 \mathrm{mM} \mathrm{Na}_{2} \mathrm{~S}_{2} \mathrm{O}_{8}, 80.0 \mathrm{mM}$ sodium borate buffer (initial pH 9.0).

not decrease obviously, indicating $\mathrm{Fe}_{2} \mathrm{O}_{3}-6.0$ has excellent cycle stability. We further analyzed the valence states and surface properties of the sample $\mathrm{Fe}_{2} \mathrm{O}_{3}-6.0$ before and after the photocatalytic reaction by XPS. Fig. 11a and (b) show the highresolution XPS spectra of $\mathrm{Fe} 2 \mathrm{p}$ and $\mathrm{O} 1 \mathrm{~s}$ before and after the reaction. The binding energy of each element has not changed. Therefore, we conclude that the superior performance stability can be ascribed to the stable structure.

The charge transfer kinetics was studied utilizing photocurrent response and electrochemical impedance spectroscopy (EIS). The photocurrent response curves (Fig. 12a) show an intensity order: $\mathrm{Fe}_{2} \mathrm{O}_{3}-6.0>\mathrm{Fe}_{2} \mathrm{O}_{3}-4.0>\mathrm{Fe}_{2} \mathrm{O}_{3}-2.0>\mathrm{Fe}_{2} \mathrm{O}_{3}-1.2$, demonstrating $\mathrm{Fe}_{2} \mathrm{O}_{3}-6.0$ with optimal charge separation efficiency. EIS plot (Fig. 12b) discloses $\mathrm{Fe}_{2} \mathrm{O}_{3}-6.0$ has the fastest
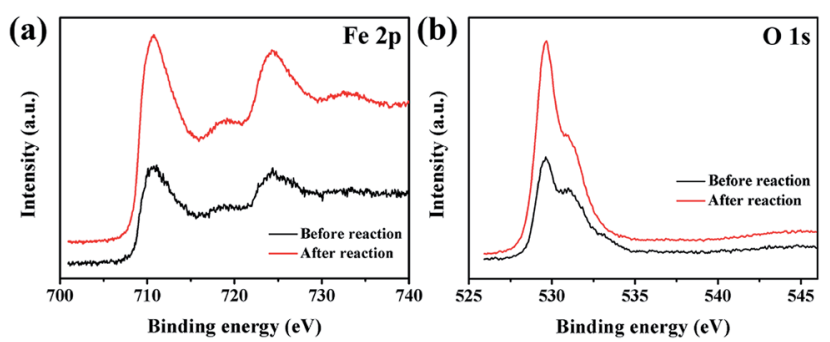

Fig. 11 XPS spectra of $\mathrm{Fe}_{2} \mathrm{O}_{3}-6.0$ before and after photocatalytic reaction, $\mathrm{Fe} 2 \mathrm{p}(\mathrm{a})$ and $\mathrm{O}$ 1s (b). 

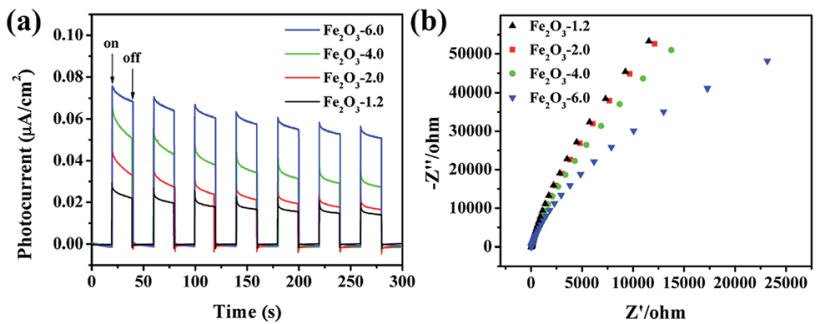

Fig. 12 (a) Photocurrent response diagrams of the $\mathrm{Fe}_{2} \mathrm{O}_{3}-x$ under visible irradiation; (b) EIS Nyquist plots of the $\mathrm{Fe}_{2} \mathrm{O}_{3}-X$.

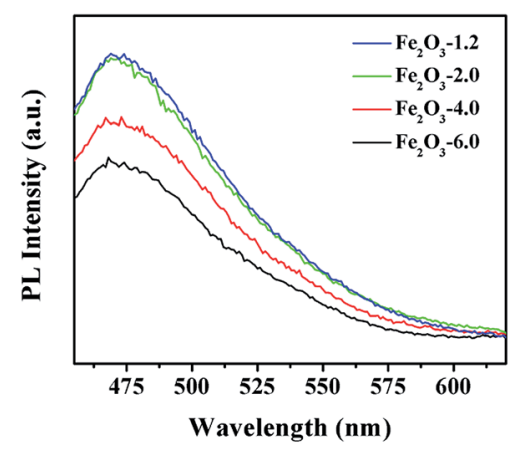

Fig. $13 \mathrm{PL}$ spectra of the as-prepared $\mathrm{Fe}_{2} \mathrm{O}_{3}$ samples.

electron transport according to the smallest semicircular, corresponding to the photocurrent result. For further investigating the separation and recombination of electron-hole pairs, the photoluminescence (PL) spectra of the catalysts were recorded at room temperature. As shown in Fig. $13, \alpha-\mathrm{Fe}_{2} \mathrm{O}_{3}$ has a strong peak near $470 \mathrm{~nm}$ which attributed to the excitonic PL spectrum. ${ }^{46}$ The dramatically decreased PL intensity of the $\alpha-\mathrm{Fe}_{2} \mathrm{O}_{3}$ samples reflects the higher separation efficiency of photoinduced electron-hole pairs and higher photocatalytic activity, ${ }^{47}$ which can be ascribed to the shorten transportation path of photogenerated electrons and holes resulting from the reduction of catalyst size. ${ }^{48}$

\section{Conclusions}

In summary, we prepared high-index faceted $\alpha-\mathrm{Fe}_{2} \mathrm{O}_{3}$ with different sizes in a facile way. We demonstrated that the photocatalytic oxygen evolution efficiency of $\alpha-\mathrm{Fe}_{2} \mathrm{O}_{3}$ nanocrystals is strongly dependent on the size. Moreover, the optimal size and high-indexed $\{104\}$ planes endow rhombohedral $\alpha-\mathrm{Fe}_{2} \mathrm{O}_{3}$ with excellent water oxidation performance. This study offers a feasible way for the construction of highly efficient water oxidation catalysts through the size tuning of high-index faceted materials.

\section{Conflicts of interest}

There are no conflicts of interest to declare.

\section{Acknowledgements}

This work was kindly supported by the Natural Science Foundation of China (No. 51564045), the Natural Science Foundation of Xinjiang University (No. BS150232), Open Fund of Guangdong Provincial Key Laboratory of Petrochemical Pollution Process and Control, and Guangdong University of Petrochemical Technology (No. 2018B030322017). The authors acknowledge facilities and staff at the Physical and Chemical testing center of Xinjiang University.

\section{References}

$1 \mathrm{~J}$. Li, R. Guttinger, R. More, F. Song, W. Wan and G. R. Patzke, Chem. Soc. Rev., 2017, 46, 6124-6147.

2 G. Chen, L. Chen, S. M. Ng and T. C. J. C. Lau, ChemSusChem, 2014, 7, 127-134.

3 F. A. Frame, T. K. Townsend, R. L. Chamousis, E. M. Sabio, T. Dittrich, N. D. Browning and F. E. Osterloh, J. Am. Chem. Soc., 2011, 133, 7264-7267.

4 J. Sato, N. Saito, Y. Yamada, K. Maeda, T. Takata, J. N. Kondo, M. Hara, H. Kobayashi, K. Domen and Y. Inoue, J. Am. Chem. Soc., 2005, 127, 4150-4151.

5 Z. Wan, Q. Xu, H. Li, Y. Zhang, Y. Ding and J. Wang, Appl. Catal., B, 2017, 210, 67-76.

6 Q. Xu, H. Li, L. Chi, L. Zhang, Z. Wan, Y. Ding and J. Wang, Appl. Catal., B, 2017, 202, 397-403.

7 S. M. Barnett, K. I. Goldberg and J. M. Mayer, Nat. Chem., 2012, 4, 498.

8 G. C. Dismukes, R. Brimblecombe, G. A. Felton, R. S. Pryadun, J. E. Sheats, L. Spiccia and G. F. Swiegers, Acc. Chem. Res., 2009, 42, 1935-1943.

9 R. Brimblecombe, A. Koo, G. C. Dismukes, G. F. Swiegers and L. Spiccia, J. Am. Chem. Soc., 2010, 132, 2892-2894.

10 S. Sun, G. Shen, J. Jiang, W. Mi, X. Liu, L. Pan, X. Zhang and J.-J. Zou, Adv. Energy Mater., 2019, 9, 1901505.

11 F. Amano, E. Ishinaga and A. Yamakata, J. Phys. Chem. C, 2013, 117, 22584-22590.

12 G. R. Bamwenda, T. Uesigi, Y. Abe, K. Sayama and H. Arakawa, Appl. Catal., A, 2001, 205, 117-128.

13 J. Huang, Y. Zhang and Y. Ding, ACS Catal., 2017, 7, 18411845.

14 S. J. Kim, Y. Lee, D. K. Lee, J. W. Lee and J. K. Kang, J. Mater. Chem. A, 2014, 2, 4136-4139.

15 J. Zhu, Z. Yin, D. Yang, T. Sun, H. Yu, H. E. Hoster, H. H. Hng, H. Zhang and Q. Yan, Energy Environ. Sci., 2013, 6, 987-993.

16 Y.-C. Zhang, N. Afzal, L. Pan, X. Zhang and J.-J. Zou, Adv. Sci., 2019, 6, 1900053.

17 W. C. Ellis, N. D. McDaniel, S. Bernhard and T. J. Collins, J. Am. Chem. Soc., 2010, 132, 10990-10991.

18 T. K. Townsend, E. M. Sabio, N. D. Browning and F. E. Osterloh, Energy Environ. Sci., 2011, 4, 4270-4275.

19 J. Zhu, Z. Yin, D. Yang, T. Sun, H. Yu, H. E. Hoster, H. H. Hng, H. Zhang and Q. Yan, Energy Environ. Sci., 2013, 6, 987-993. 
20 Z. Lin, C. Du, B. Yan and G. Yang, Catal. Sci. Technol., 2019, 9, 5582-5592.

21 Z. Guo, G. Chen, C. Cometto, B. Ma, H. Zhao, T. Groizard, L. Chen, H. Fan, W.-L. Man and S.-M. J. N. C. Yiu, Nat. Catal., 2019, 2, 801-808.

22 A. Kusior, K. Michalec, P. Jelen and M. Radecka, Appl. Surf. Sci., 2019, 476, 342-352.

23 M. R. Abhilash, A. Gangadhar, J. Krishnegowda, M. Chikkamadaiah and S. Srikantaswamy, RSC Adv., 2019, 9, 25158-25169.

24 G. Shen, L. Pan, Z. Lü, C. Wang, F.-e. Aleem, X. Zhang and J.-J. Zou, Chin. J. Catal., 2018, 39, 920-928.

25 X. She, J. Wu, H. Xu, J. Zhong, Y. Wang, Y. Song, K. Nie, Y. Liu, Y. Yang and M. T. F. Rodrigues, Adv. Energy Mater., 2017, 7, 1700025.

26 L. Li, X. She, J. Yi, L. Pan, K. Xia, W. Wei, X. Zhu, Z. Chen, H. Xu and H. Li, Appl. Surf. Sci., 2019, 469, 933-940.

27 H. Liu, K. Tian, J. Ning, Y. Zhong, Z. Zhang and Y. Hu, ACS Catal., 2019, 9, 1211-1219.

28 F. Meng, J. Li, S. K. Cushing, J. Bright, M. Zhi, J. D. Rowley, Z. Hong, A. Manivannan, A. D. Bristow and N. Wu, ACS Catal., 2013, 3, 746-751.

29 X.-T. Xu, L. Pan, X. Zhang, L. Wang and J.-J. Zou, Adv. Sci., 2019, 6, 1801505.

30 Z.-S. Pourbakhsh, K. Mohammadi, A. Moshaii, M. Azimzadehirani and A. Hosseinmardi, RSC Adv., 2019, 9, 31860-31866.

31 Q. Xiang, G. Chen and T.-C. Lau, $R S C A d v ., 2015$, 5, 5221052216.

32 Y. L. Wang, Y. H. Li, X. L. Wang, Y. Hou, A. P. Chen and H. G. Yang, Appl. Catal., B, 2017, 206, 216-220.

33 Y. Ma, J. Yang, Y. Yuan, H. Zhao, Q. Shi, F. Zhang, C. Pei, B. Liu and H. Yang, Langmuir, 2017, 33, 8671-8678.

34 Y. Zhao, D. Yan, C. Ding, D. Su, Y. Ge, Y. Zhao, H. Zhou, J. Li and H. Jin, J. Power Sources, 2016, 327, 658-665.
35 X. Rao, X. Su, C. Yang, J. Wang, X. Zhen and D. Ling, CrystEngComm, 2013, 15, 7250-7256.

36 G. Zhang, Y. Shi, H. Wang, L. Jiang, X. Yu, S. Jing, S. Xing and P. Tsiakaras, J. Power Sources, 2019, 416, 118-124.

37 A. Patterson, Phys. Rev., 1939, 56, 978.

38 J. S. Hu, L. S. Zhong, W. G. Song and L. J. Wan, Adv. Mater., 2008, 20, 2977-2982.

39 W. Yang, F. Gao, G. Wei and L. An, Cryst. Growth Des., 2009, 10, 29-31.

40 K. He, B. Song, L. Zhan, W. Lu, J. Li, G. Zhao and G. Han, CrystEngComm, 2016, 18, 754-758.

41 J. Cai, S. Chen, J. Hu, Z. Wang, Y. Ma and L. Qi, CrystEngComm, 2013, 15, 6284-6288.

42 R. D. Rodriguez, D. Demaille, E. Lacaze, J. Jupille, C. Chaneac and J.-P. Jolivet, J. Phys. Chem. C, 2007, 111, 16866-16870.

43 M. Lin, H. R. Tan, J. P. Y. Tan and S. Bai, J. Phys. Chem. C, 2013, 117, 11242-11250.

44 A. I. Ekimov, A. L. Efros and A. A. Onushchenko, Solid State Commun., 1985, 56, 921-924.

45 J. P. Perdew, R. G. Parr, M. Levy and J. L. Balduz Jr, Phys. Rev. Lett., 1982, 49, 1691.

46 L. Yu, Y. Zhang, J. He, H. Zhu, X. Zhou, M. Li, Q. Yang and F. Xu, J. Alloys Compd., 2018, 753, 601-606.

47 X. An, D. Cheng, L. Dai, B. Wang, H. J. Ocampo, J. Nasrallah, X. Jia, J. Zou, Y. Long and Y. Ni, Appl. Catal., B, 2017, 206, 5364.

48 F. E. Osterloh, Chem. Soc. Rev., 2013, 42, 2294-2320.

49 M. Zhang, J. Luo, X. Liang, B. Yan, M. Baikenov, X. Su, L. Chi and C. Yang, Mater. Lett., 2018, 210, 73-76.

50 L. Chi, Q. Xu, X. Liang, J. Wang and X. Su, Small, 2016, 12, 1351-1358.

51 D. Hong, Y. Yamada, T. Nagatomi, Y. Takai and S. Fukuzumi, J. Am. Chem. Soc., 2012, 134, 19572-19575. 